\title{
UPAYA PENINGKATAN KEMAMPUAN GURU SEKOLAH DASAR DALAM PEMBELAJARAN BERPUSAT KOOPERATIF MELALUI SUPERVISI KLINIS DI SD NEGERI O2 KARAN AUR KOTA PARIAMAN TAHUN 2020
}

\author{
NURUL HUDA \\ SD Negeri 02 Karan Aur Kota Pariaman
}

\begin{abstract}
The objectives of this school action research are; To find out the ability of elementary school teachers with a cooperative learning model through clinical supervision at SD Negeri 02 Karan Aur, Kota Pariaman. The research subjects were 8 teachers of SD Negeri 02 Karan Aur. The results of the analysis that has been carried out using clinical supervision in improving the ability of teachers to use cooperative models are very good. At the beginning of the activity the teacher was still hesitant to use this model, but because of the guidance of researchers through clinical supervision, the teacher was able to use the cooperative model. $87 \%$ of teachers are able to use cooperative models in the learning process and this also affects the potential of students.
\end{abstract}

Keywords: Capacity Building, Elementary School Teachers, Cooperative, Clinical Supervision.

\begin{abstract}
Abstrak: Tujuan penelitian tindakan sekolah ini adalah ; Untuk mengetahui besar kemampuan guru Sekolah Dasar dengan model pembelajaran kooperatif melalui supervisi klinis di SD Negeri 02 Karan Aur Kota Pariaman. Subyek penelitian adalah guru SD Negeri 02 Karan Aur sebanyak 8 orang guru. Hasil analisa yang telah dilaksanakan dengan mempergunakan supervisi klinis dalam meningkatkan kemampuan guru untuk mempergunakan model kooperatif sangat bagus. Pada awal kegiatan guru masih ragu untuk mempergunakan model tersebut, tapi karena adanya bimbingan peneliti melalui supervisi klinis maka guru sudah mampu mempergunakan model kooperatif. 87\% guru sudah mampu mempergunakan model kooperatif dalam proses pembelajaran dan ini juga berpengaruh terhadap potensi siswa.
\end{abstract}

Kata Kunci: Peningkatan Kemampuan, Guru Sekolah Dasar, Kooperatif, Supervisi Klinis.

\section{A. Pendahuluan}

Pendidikan adalah proses merubah manusia menjadi lebih baik, lebih mahir dan lebih terampil. Untuk mencapai tujuan tersebut tentunya dibutuhkan strategi yang disebut dengan strategi pembelajaran. Dalam strategi pembelajaran terkandung tiga hal pokok yakni perencanaan, pelaksanaan dan evaluasi maka terbentuklah pembelajaran yang bermutu. Pembelajaran yang bermutu di sekolah merupakan kewajiban bagi guru secara umum, namun demikian hal ini masih belum dilakukan dengan maksimal oleh guru, dan mereka belum banyak kreatif menggunakan model-model pembelajaran maupun teknik-teknik pendekatan yang baru. Seolah-olah guru hanya menyampaikan materi pelajaran saja, kurang kontrol terhadap kondisi siswa saat pembelajaran berlangsung.

Guru-guru di kelas rata-rata belum memberdayakan strategi gaya dan seni mengajar yang maju. Di SD Negeri 02 Karan Aur Kota Pariaman berdasarkan hasil supervisi rutin peneliti sebagai Kepala Sekolah, ternyata sebagian besar guru masih melaksanakan pembelajaran yang tradisional, di mana guru dalam melaksanakan 
pembelajaran tanpa menggunakan RPP yang dibuat sendiri, mereka cenderung menggunakan RPP cetakan yang ada dan belum melaksanakan pembelajaran berpusat Kooperatif. Guru masih banyak melaksanakan pembelajaran dengan metode ceramah murni belum rutin bervariasi, maupun belum menggunakan alat peraga, dan tampaknya guru masih sebagai penyampai materi bentuk klasikal, belum banyak melakukan pembelajaran yang kreatif model kooperatif, yang dapat melatih mandiri dan tanggungjawab para peserta didik.

Hal ini dapat dilihat dari hasil supervisi yang telah dilaksanakan oleh peneliti pada guru yang ada di SD Negeri 02 Karan Aur Kota Pariaman sebanyak 8 orang yang tersebar dalam guru kelas, guru PAI, guru PJOK, ternyata rata-rata guru belum mampu melaksanakan pembelajaran berpusat kooperatif secara maksimal. Dari hasil supervisi rutin dapat dilihat secara nyata bahwa guru masih melaksanakan pembelajaran yang biasa-biasa saja. Pembelajaran yang dilakukan hanya menggunakan metode ceramah tanpa ada variasi dan kurang memanfaatkan peluang, membentuk kelompok-kelompok kecil dikelasnya. Kegiatan pembelajaran di SD Negeri 02 Karan Aur Kota Pariaman masih tergolong rendah dan kemampuan guru dalam mengajar belum berpusat pada model pembelajaran kooperatif secara optimal. Terdapat bukti prestasi para siswa masih rendah belum sesuai dengan harapan lembaga sekolah orang tua dan masyarakat.

Dilihat dari frekuensi pelaksanaan supervisi oleh kepala sekolah juga belum optimal. Dari data supervisi dapat dilihat dalam satu bulan supervisi yang dilakukan, mungkin hanya beberapa kali atau tidak sama sekali. Supervisi yang dilakukan masih terkesan melaksanakan pemantauan saja, seolah-olah hanya melihat dokumen dan hanya memotret keadaan saat terjadi di sekolah tanpa ada tindakan yang nyata menuju perbaikan pembelajaran selanjutnya. Apabila semua guru dalam melaksanakan tugasnya setiap hari mengajar dengan berpusat kooperatif di kelasnya, maka dapat dikatakan, bahwa hasil dari proses pembelajaran itu akan tercapai memuaskan, yang pada gilirannya akan meningkatkan prestasi belajar para peserta didiknya.

Kemampuan guru dalam melaksanakan model pembelajaran kooperatif melalui supervisi klinis oleh Kepala sekolah, dengan bimbingan arahan kesadaran tinggi diharapkan para guru dapat melakukan pembelajaran bermutu, sehingga mempengaruhi positif terhadap perilaku peserta didik dan menambah kemajuan prestasi belajar mereka. Pelaksanaan supervisi yang dilakukan peneliti berupaya mengubah kegiatan mengajar guru yang lebih baik dengan menggunakan instrumen khusus tentang pembelajaran di kelasnya. Maka sasaran supervisi mampu mengubah perilaku guru untuk lebih berkreatif dalam melaksanaan tugas mengajar yang menarik disukai peserta didik. Oleh karena itu proses pembelajaran diharapkan selalu terlaksana dengan menyenangkan, para peserta didik dapat memusatkan perhatiannya untuk belajar bersama teman-temannya.

Keberhasilan proses pembelajaran dapat ditentukan oleh sering dan tidaknya supervisi yang dilakukan oleh kepala sekolah maupun Kepala sekolah, karena guru akan termotivasi kemampuannya dalam melaksanakan tugas manakala ada respon baik antara kepala sekolah, guru maupun Kepala sekolah. Antara guru, kepala sekolah, dan Kepala sekolah, merupakan komponen utama yang harus memberdayakan diri agar mampu memajukan prestasi belajar peserta didik, maka dalam hal ini peneliti sebagai Kepala sekolah berupaya melakukan supervisi klinis terutama di dalam kelas.

Berdasarkan pernyataan di atas dan memecahkan permasalah tersebut maka peneliti ingin mengadakan penelitian dengan judul 'Upaya peningkatan kemampuan guru Sekolah Dasar dalam pembelajaran berpusat kooperatif melalui supervisi klinis di 
SD Negeri 02 Karan Aur Kota Pariaman Tahun 2020. Berdasarkan uraian di atas dapat dirumuskan masalah sebagai berikut : "Apakah melalui supervisi klinis dapat meningkatkan kemampuan guru SD dengan model pembelajaran kooperatif di SD Negeri 02 Karan Aur Kota Pariaman. Tujuan penelitian tindakan sekolah ini adalah ; Untuk mengetahui besar kemampuan guru Sekolah Dasar dengan model pembelajaran kooperatif melalui supervisi klinis di SD Negeri 02 Karan Aur Kota Pariaman.

\section{B. Metodologi Penelitian}

Lokasi tempat untuk melakukan penelitian tindakan sekolah ini adalah di SD Negeri 02 Karan Aur Kota Pariaman Hal ini dikarenakan SD Negeri 02 Karan Aur tersebut merupakan sekolah yang peneliti selaku Kepala Sekolahnya.Sedangkan waktu penelitian direncanakan pada bulan Januari sampai bulan Maret 2020. Subyek penelitian adalah guru SD Negeri 02 Karan Aur sebanyak 8 orang guru, yang berdasarkan hasil supervisi rutin, guru - guru tersebut masih memiliki kemampuan yang rendah dalam pelaksanaan pembelajaran dengan beraneka model dan belum maksimal dalam melaksanakan pembelajaran dengan pendekatan kooperatif. Pelaksnaan penelitian yang di lakukan pada semester 2 TP 2019/2020 yang di mulai pada bulan Januari sampai bulan Maret 2020. Tindakan yang dilakukan adalah berupa supervisi klinis yang akan dilakukan secara bertahap yaitu ; siklus I supervisi dilakukan menggunakan supervisi klinis secara kelompok yang terdirir dari perencanaan, pelaksanaan, pengamatan dan refleksi, kemudian dilanjutkan ke siklus II dilakukan supervisi klinis secara individual yang terdiri dari tahap perencanaan, pelaksanaan tindakan, pengamatan/observasi dan refleksi. Data awal penelitian ini adalah berupa hasil supervisi secara rutin dari peneliti sebagai Kepala Sekolah, serta data akhir diperoleh melalui observasi, dokumentasi dan pengisian lembar instrumen penelitian. Instrumen penelitian berupa lembar observasi dan lembar penilaian, yang berguna untuk mencatat semua peristiwa pelaksanaan tugas guru dalam pembelajaran selama penelitian berlangsung. Analisis data yang digunakan peneliti dengan menggunakan analisis deskriptif komparatif, yaitu dengan membandingkan pelaksanaan pembelajaran pendekatan kooperatif sebelum dilaksanakan supervisi klinis, dan pembelajaran sesudah dilakukan supervisi klinis.

\section{Hasil dan pembahasan}

\section{Hasil Penelitian Tindakan}

Pada bagian ini dikemukakan hasil penelitian siklus I sesuai dengan perencanaan kegiatan subyek penelitian terdiri dari guru kelas SD Negeri 02 Karan Aur Pariaman Tahun Pelajaran 2019/2020 yang berjumlah 8 orang. Guru tersebut sudah siap dengan perlengkapannya untuk dilaksanakan supervisi klinis. Sebelum dilaksanakan supervisi klinis maka peneliti mengamati proses pembelajaran yang dilaksanakan guru di kelas. Hasil pengamatan oleh peneliti hanya 1 orang guru yang melaksanakan proses pembelajaran dengan model kooperatif di kelas rendah dan 1 orang di kelas tinggi. Untuk meningkatkan kemampuan guru dalam menerapkan model kooperatif dalam proses pembelajaran maka peneliti melaksanakan supervisi klinis terhadap guru agar guru mampu mempergunakannya.

Untuk menjawab masalah itu maka penelitian diadakan dua siklus sesuai dengan perencanaan, setelah diadakan penelitian sampai pada dua siklus maka terdapatlah hasil yang signifikan. Pada pelaksanaan setiap siklus guru di beri angket dan kuisioner yang akan diisi pada saat siklus berakhir. 


\section{Hasil penelitian Siklus I}

Sesuai dengan rencana yang telah di susun, maka penelitisebagai kepala sekolah memberikan beberapa pedoman untuk membimbing guru dalam pelaksanaan proses pembelajaran. Pedoman yaitu Permendiknas no. 41 tahun 2007 yaitu standar proses dan berbagai sumber tentang pembelajaran kooperatif. Pedoman pengelolaan tersebut berisi tentang model-model kooperatif yang bisa di gunakan dalam proses pembelajaran. Pelaksanaan siklus I sesuai dengan perencanaan yang telah di buat dalam metodologi penelitian. Pada siklus I di laksanakan supervisi klinis, setelh proses pembelajaran yang dilaksanakan secara,berkelompok. Pelaksnaan supervisi klinis adalah membimbing atau pembinaan terhadap guru untuk mempergunakan model pembelajaran kooperatif dalam proses pembelajaran sesuai dengan standar proses.

Supervisi klinis dilaksanakan berkaitan dengan pengelolaan pembelajaran kooperatif yang diterapkan oleh guru. Model kooperatif ini banyak macamnya, dan guru boleh memilih model apa yang diterapkan dalam proses pembelajaran. Model kooprtaif ini sangat bagus dilaksanakan sebab mampu membangkitkan semangat dan motivasi siswa dalam pembelajaran, maka di terapkan model ini. Peneliti melakukan pengamatan tehadap proses pembelajaran yang dilakukan guru dengan menggunakan model kooperatif. Hasil pengamatan yang di peroleh dalam proses pembelajaran adalah sebagai berikut:

Tabel 1 Kemampuan Guru Siklus I

\begin{tabular}{|l|l|l|c|}
\hline No & Kategori & Jumlah & $\%$ \\
\hline 1 & Amat Baik & & \\
\hline 2 & Baik & 1 & \\
\hline 3 & Cukup & 4 & \\
\hline 4 & Kurang & 3 & \\
\hline 5 & Rerata & & \\
\hline
\end{tabular}

Dari tabel diatas dapat di ketahui bahwa kemampuan guru dalam proses pembelajaran dengan menggunkan model kooperatif masih rendah, karena biasa guru menerapkan sistem ceramah sehingga guru masih belum terbiasa mempergunakan model kooperatif. Dari hasil pengamatan dinyatakan bahwa kemampuan guru dalam proses pembelajaran pada siklus I ini masih kategori rendah, hanya 5 orang $(63 \%)$ guru SD Negeri 02 Karan Aur yang mampu menerapkan model kooperatif dalam proses pembelajaran, hal ini belum mancapai indikator yang diinginkan. Karena belum mencapai keinginan maka di lanjutkan ke siklus II. Sebelum masuk siklus II maka peneliti menyuruh guru untuk melaksanakan simulasi agar pelaksanaan pembelajaran terlaksana dengan bagus. Peneliti juga memberikan bimbingan secara individu terhadap guru atau supervisi klinis agar guru mampu menerapkan pembelajaran kooperatif dalam proses.

\section{Hasil Penelitian Siklus II}

Pelaksanaan siklus II sama dengan siklus I, yaitu memberikan bimbingan pada guru dengan menggunakan supervisi klinis secara individu. Pertama yang dilakukan peneliti melihat RPP yang sudah di susun oleh guru dan di analisis, dan memberikan bimbingan tentang pelaksanaan model kooperatif. Pelaksanaan supervisi klinis atau pembinaan serta pembimbingan terhadap guru terus berlangsung agar pelaksanaan proses pembelajaran kooperatif terlaksana dengan baik. Pembimbingan dilakukan secara individual, hal ini dilaksanakan agar bisa diketahui kelemahan masing-masing 
guru. Dalam pelaksanaan supervisis klinis secara individu peneliti menjelaskan kembali tujuan pelaksanaan pembimbingan tersebut.

Pembimbingan ini mengkaji juga RPP yang telah di susun guru, sebab RPP ini adalah pedoman bagi guru dalam pelaksanaan pembelajaran di kelas. Sebelum melaksanakan proses pembelajaran peneliti kembali menyuruh guru untuk melaksanakan simulasi tentang pelaksanaan model pembelajaran kooperatif dalam prposes, sehingga peneliti bisa mengetahui apakah guru sudah mampu menerapkan model kooperatif serta menyusun RPP sesuai dengan model kooperatif.

Hasil pengamatan yang di peroleh peneliti di lapangan dengan melaksanakan pembimbingan atau supervisi klinis yaitu kemampuan guru kelas rendah sudah bagus dalam penerapan model koopeartif dalam proses pembelajaran, begitu juga guru kelas tinggi. Dengan hasil yang demikian dengan menggunakan supervisi klinis berhasil meningkatkan kemampuan guru dalam proses pembelajaran dengan menggunakan model koopeartif seperti yang tertuang dalam Standar Proses. Hasil perolehan yang didapat adalah sebagai berikut

Tabel 2 Kemampuan Guru Siklus II

\begin{tabular}{|l|l|l|l|}
\hline No & Kategori & Jumlah & \multicolumn{2}{|c|}{$\%$} \\
\hline 1 & Amat Baik & 1 & 12,5 \\
\hline 2 & Baik & 5 & 62,5 \\
\hline 3 & Cukup & 2 & 25 \\
\hline 4 & Kurang & & \\
\hline
\end{tabular}

Hasil dari tabel diatas dapat di lihat bahwa pada siklus II ini pelaksanaan pembeajaran yang di laksanakan guru sudah bagus, tidak terdapat lagi kesalahan. Dengan melihat hasil dari tabel diatas maka dapat di ketahui bahwa dengan menggunakan supervisi klinis dapat meningkatkan kemampuan guru dalam proses pembelajaran, terutama dalam proses pembelajaran yang mengunakan model kooperatif learning.

\section{Pembahasan}

Pada pembahasan ini di lakukan untuk melihat kemampuan guru dalam proses pembelajaran, tapi sebelumnya di lihat perangkat pembelaaran terutama RPP guru. Untuk pelaksanaan penelitian maka peneliti mempersiapkan angket untuk mencatat apa yang di temui pada tahap pendahuluan di lapangan waktu pelaksanaan supervisi klinis. Pelaksanaan supervisi klinis secara kelompok yaitu, peneliti menjelaskan tujuan supervisi klinis, langkah-langkah kegiatan dan pelaksanaan supervisi klinis. Sebelum di laksanakan supervisi klinis peneliti menginformasikan kepada guru untuk mengumpulkan perangkat.

Dari hasil analisa tersebut kita menekankan pada model pembelajaran. Tapi sebelum model pembelajaran peneliti juga mengaanlisa tentang indikator dan tujuan pembelajaran yang di susun. Berdasarkan hasil tersebut maka peneliti memberikan bimbingan pada guru untuk menyusun RPP sesuai dengan Standar isi, serta ada model atau metode yang bervariasi tercantum serta di laksanakan dalam proses pembelajaran sehingga siswa akan termotivasi untuk belajar dan bisa meningkatkan hasil belajar siswa. Untuk lebih jelas rekap hasil analisa guru tentang kegiatan dalam proses pembelajaran yang di susun oleh guru melalui supervisi klinis secara kelompok

Tabel 3 Kemampuan Guru Siklus I

\begin{tabular}{|l|l|l|c|}
\hline No & Kategori & Jumlah & $\%$ \\
\hline 1 & Amat Baik & & \\
\hline
\end{tabular}




\begin{tabular}{|l|l|l|l|}
\hline 2 & Baik & 1 & \\
\hline 3 & Cukup & 4 & \\
\hline 4 & Kurang & 3 & \\
\hline 5 & Rerata & & \\
\hline
\end{tabular}

Dari hasil analisa dengan menggunkan supervisi klinis secara kelompok dapat di ketahui bahwa guru masih memakai model lama yaitu teacher center, aktivitas yang banyak adalah guru, siswa hanya mendengarkan apa yang di katakan guru. Untuk meningkatkan kemampuan guru dalam memakai model kooperatif yang beraneka ragam maka guru melanjutkan supervisi klinis secara individu yaitu memberikan bimbingan kepada guru bagaimana pemakaian model kooperatif dalam proses pembelajaran. Setelah itu peneliti masuk ke kelas di mana guru itu mengajar. Ini adalah lanjutan siklus II.

Untuk melanjutkan penelitian dengan supervisi klinis pada guru maka peneliti mempersiapkan angket untuk pengamatan di lapangan, juga meminta pada guru RPP yang sudah di perbaiki. Untuk pelaksanaan siklus II penelitian ini sesuai dengan perencanaan yang telah di susun. Peneliti melihat dan mendengarkan guru melaksanakan proses pembelajaran, hal ini di lakukan peneliti karena mempergunakan supervisi klinis. Peaksanaan pengamatan selama 2 am pembelajaran. Peneliti sebagai kepala sekolah berusaha untuk meningkatkan kompetensi guru dalam proses pembelajaran dengan menggunakan model kooperatif learning, maka peneliti memberikan bimbingan untuk menggunakan model kooperatif tersebut secara kelompok. Pada siklus II hasil analisa paneliti terhadap kemampuan guru dalam mempergunakan model kooperatif adalah sebagai berikut

Tabel 2 Kemampuan Guru Siklus II

\begin{tabular}{|l|l|l|l|}
\hline No & Kategori & Jumlah & \multicolumn{2}{|c|}{$\%$} \\
\hline 1 & Amat Baik & 1 & 12,5 \\
\hline 2 & Baik & 5 & 62,5 \\
\hline 3 & Cukup & 2 & 25 \\
\hline 4 & Kurang & & \\
\hline
\end{tabular}

Sesuai dengan tabel diatas maka hasil analisa peneliti dengan menggunakan supervisi klinis secara inidividu bahwa guru sudah mampu mempergunakan model kooperatif dalam proses pembelajaran. dengan demkian untuk meningkatkan kemampuan guru dalam proses pembelajaran dengan menggunakan model kooperatif berhasil melalui supervisi klinis.

\section{Penutup}

Berdasarkan hasil analisa di atas tentang mempergunakan supervisi klinis dalam meningkatkan kemampuan guru untuk mempergunakan model kooperatif sangan bagus. Pada awal kegiatan guru masih ragu untuk mempergunakan model tersebut, tapi karena adanya bimbingan peneliti melalui supervisi klinis maka guru sudah mampu mempergunakan model kooperatif. Model kooperatif ini sangat bagus, mampu meningkatkan aktivitas dan hasil belajar siswa, serta siswa bersemangat untuk belajar. Maka kepala sekolah di sekolah lainnya di sarankan untuk membimbing an memberikan pengarahan pada gurunya untuk mempergunakan model kooperatif ini. Cara yang dipakai untuk meningkatkan k0mpetensi guru dalam proses pembelajaran bisa melalui supervisi klinis, IHT atau Worshop dan sebagainya 


\section{Daftar Pustaka}

Dirjen PMPTK. 2010 .Penelitian Tindakan Sekolah, Jakarta : Kemendiknas.

Dirjen PMPTK. 2010 .Supervisi Akademik, Jakarta : Kemendiknas.

Moh. User Usman, 1995 .Menjadi guru professional.Jakarta :

Moh. User Usman, 2007 . Permendiknas No 41/ 2007. Jakarta : Kemendiknas.

Purwodarminto, WJS.Kamus Bahasa Indonesia, Jakarta : Balai Pustaka.

Saifudin, 2007 .Metode Penelitian, Yogyakarta : Pustaka Pelajar.

Suharsimi Arikunto, 2004 .Prosedur Penelitian. Jakarta : Rineksa Cipta.

Sugiyanto, 2010.Model-model Pembelajaran Inovatif. Surakarta: Yuma Pressindo

Bintoro Wahyu R — Minggu, 09 Juli 2017 — PTS 